\title{
Scientific support and advanced research in dairy farming in the Russian Federation
}

\author{
Tatiana Marinchenko* \\ Russian Research Institute of Information and Feasibility Study on Engineering Support of \\ Agribusiness, the Federal State Budgetary Scientific Institution (Rosinformagrotekh FSBSI), 60, \\ Lesnaya Str., Pravdinsky Township, 141261 Moscow Region, Russian Federation
}

\begin{abstract}
Increasing the output of agricultural products and improving their quality is one of the most important tasks of ensuring the food security of the Russian Federation. The solution to this problem is impossible without the introduction of up-to-date technologies that ensure the competitiveness and output growth, which are the result of scientific research and development. The basis for increasing the efficiency of dairy farming and, as a consequence, increasing milk production is the genetic improvement of the breeding base. The organization of selection and breeding work based on the use of our own genetic resources is a strategic task of the industry, which allows increasing the output of livestock products, reducing the technological import dependence of animal husbandry and minimizing the risk of the introduction of infectious diseases into the country. At the same time, the breeding base of dairy cattle breeding is on average $13.8 \%$ of the total livestock in the Russian Federation. The breeding progress is ensured by agricultural organizations, in which less than half of the total head of cows is concentrated. They are also the main consumers of research and development results. The purpose of the study is to analyze the state of the industry and its scientific potential, as well as formulate proposals for improving scientific support to create conditions for solving the tasks set by the state.
\end{abstract}

\section{Introduction}

Milk and dairy products occupy one of the leading places in the diet and are extremely important for a balanced human nutrition. However, in recent years, the consumption of dairy products in Russia has been at a level significantly lower than $325 \mathrm{~kg}$ per person annually, which the Russian Ministry of Health recommends. If the consumption of dairy products was $387 \mathrm{~kg}$ per person annually in 1990, then, according to the National Union of Milk Producers (here in after referred to as Soyuzmoloko), the average per capita milk consumption in Russia was $240 \mathrm{~kg}$ per person in 2020 [1]. Forty two percents of the total cow population is concentrated in agricultural organizations (AO), which output more than half of the milk produced in the country. Personal subsidiary plots (PSP) and peasant (farm) enterprises (P (F) E) keep 58\% of the total cow population and they produce about $44 \%$ of milk in total (Table 1).

\footnotetext{
*Corresponding author:9419428@mail.ru
} 
Table 1. Production structure of dairy farming.

\begin{tabular}{|c|c|c|c|c|c|c|c|}
\hline \multirow{2}{*}{ Indicators } & \multicolumn{6}{|c|}{ Year } & \multirow{2}{*}{$\begin{array}{c}2019 \text { to } \\
2014 \text { ratio, } \\
\%\end{array}$} \\
\hline & 2014 & 2015 & 2016 & 2017 & 2018 & 2019 & \\
\hline \multicolumn{8}{|c|}{ Number of cows, million heads } \\
\hline All categories of farms & 8.3 & 8.1 & 8.0 & 8.0 & 7.9 & 7.9 & 95.1 \\
\hline $\mathrm{AO}$ & 3.4 & 3.4 & 3.4 & 3.3 & 3.38 & 3.36 & 98.8 \\
\hline$P(F) E$ & 1.1 & 1.1 & 1.2 & 1.2 & 1.3 & 1.35 & 122.7 \\
\hline PSP & 3.8 & 3.4 & 3.4 & 3.4 & 3.3 & 3.25 & 92.6 \\
\hline \multicolumn{8}{|c|}{ Milk production, million MT } \\
\hline All categories of farms & 30.0 & 29.9 & 29.8 & 30.2 & 30.6 & 31.3 & 104.3 \\
\hline $\mathrm{AO}$ & 14.4 & 14.7 & 15.1 & 15.7 & 16.2 & 17.9 & 124.3 \\
\hline $\mathrm{P}(\mathrm{F}) \mathrm{E}$ & 1.9 & 2.0 & 2.2 & 2.4 & 2.5 & 2.0 & 105.3 \\
\hline PSP & 13.7 & 13.2 & 12.6 & 12.1 & 11.9 & 11.7 & 85.4 \\
\hline
\end{tabular}

The upward trend in milk production continued in 2020, the output increased by 855,000 metric tons to 32 million metric tons. According to the forecast of the Ministry of Agriculture of Russia, milk production will reach 32.6 million metric tons in 2021 [2]. At the same time, there was for the first time an increase in the number of cows (which is estimated at 18.9 million heads) by $0.6 \%$ as compared to 2019 [1].

The main increase in milk production is due to agricultural enterprises. They carry out selection and breeding work, i.e. the main breeding progress is in populations. The agricultural enterprises are also the main consumers of the results of research and development both in the field of breeding and in the field of production processes and feeding: the demand for automatic milking systems, feed preparation and feeding systems, manure removal systems, as well as digitalization, is growing. The main consumers of innovations are large manufacturers [3].

The industry is characterized by a long payback period of capital investments, import dependence regarding equipment, technical means and consumables, and genetic material. Given the limited free financial resources that an organization can allocate for modernization and innovation, not all AO can afford them. P (F) E and PSP tend to be even more limited in finance $[4,5]$.

Despite the annual increase in milk production, its overall level does not meet the requirements of the Doctrine of Food Security of the Russian Federation (hereinafter referred to as the Doctrine), and is characterized by a lag in terms of the population milk provision level from economically developed countries, in the technological development of the production base of dairy cattle breeding, as well as a reduction in the national genetic resources of dairy cattle is observed. The level of self-sufficiency of Russia in dairy products amounted to $84.1 \%$ in 2019 , which is $5.9 \%$ lower than the threshold value specified in the Doctrine [2].

In general, the industry is currently developing in accordance with the trends and tasks characteristic of the agricultural sector, therefore, along with the general development of agriculture, which is accompanied by the introduction of advanced technologies and an increase in animal productivity, the vectors of further development of the industry are changing. According to the federal project titled 'Export of agricultural products' drafted by the Russian Ministry of Agriculture, export sales of meat and dairy products should reach $\$ 2.8$ billion by 2024 [6]. As of the beginning of 2019 , the export of dairy products was 700,000 metric tons in terms of milk, it grew by $12 \%$ and exceeded $\$ 300$ million in 2020 


\section{Materials and Methods}

The subject of the study was organizations engaged in research and development in the field of selection of dairy cattle breeding and their introduction into production. The purpose of the work is to assess their sufficiency to achieve the target indicators of the country's development. The informational basis of the study was the official data from the Federal State Statistics Service, the Ministry of Agriculture of Russia, industry unions, proceedings of research institutions, and the works of leading scientists in the field of research. Also legislative acts that had established strategic guidelines for the development of the country and the industry were used. The research was based on a general scientific methodology using methods of monographic, comparative, factorial and logical analysis, as well as an expert-analytical method for processing initial information.

\section{Results and Discussion}

It is possible to significantly accelerate the development of the dairy farming industry through using up-to-date technologies that accelerate the breeding process, establishing the interaction of the genotype and the environment and their impact on productivity, as well as increasing the share of the best genotypes in the population $[7,8,9]$.

The breeding and productive qualities of dairy cattle are improved in breeding herds of stud farms, reproducers and gene pool farms. As of 01.01 .2020 , pedigree dairy cattle breeding in Russia is represented by 1,115 pedigree herds of dairy cattle, in which 23 breeds are bred (Table 2) [10].

Table 2. Pedigree base of dairy cattle breeding.

\begin{tabular}{|l|c|c|c|}
\hline \multicolumn{1}{|c|}{ Indicator } & $\mathbf{2 0 1 7}$ & $\mathbf{2 0 1 8}$ & $\mathbf{2 0 1 9}$ \\
\hline Number of breeding herds & 1,230 & 1,120 & 1,115 \\
\hline Number of breeds raised & 22 & 22 & 23 \\
\hline Broodstock, thousand heads & 1013.3 & 1012.5 & 1046.2 \\
\hline Milk yield per cow per herd, kg & 7,241 & 7,561 & 7,650 \\
\hline $\begin{array}{l}\text { Coverage of cows with artificial } \\
\text { insemination (AO), \% }\end{array}$ & 88.5 & 86.2 & 87.0 \\
\hline $\begin{array}{l}\text { Output of young animals per 100 cows, } \\
\text { heads }\end{array}$ & 77 & 76 & 77 \\
\hline
\end{tabular}

$1,701,200$ heads of livestock were appraised in 1,074 breeding farms, including $1,052,700$ cows, in 2019 . The breeding base of dairy cattle breeding is on average $13.8 \%$ of the total livestock in the Russian Federation [10, 11], which is not optimal for the development of the market for breeding animals in this country, reflected in the shortage of domestic breeding resources and large imports of livestock from abroad for completing large industrial milk production facilities for milk.

The analysis allowed identifying the main problems in the development of the dairy farming industry:

- Lack of centralized information systems for assessing breeding resources by breed, 
- A significant increase, over the past five years, in the structure of the share of imported deep-frozen semen of servicing bulls $(20 \%$ or more) and the procurement of artificial insemination organizations mainly (about 68\%) with imported bulls,

- A weak level of pedigree recording of cows (phenotyping) for a number of indicators of productivity (milk yield, fat and protein); this recording is necessary for the development of highly efficient methods for assessing the breeding value of animals, genomic selection (the main factor in accelerating the process of improving breeds and populations) and forming reference population based on domestic breeding resources,

- Difficulties in the implementation of domestic pedigree young animals (heifers) due to the imbalance of expanded reproduction in herds,

- Lack of a system for monitoring of breeding resources as an effective economic tool to stimulate support for leaders in milk production and replacement stock,

- Significant technological and methodological lag in the development of reproductive processes that ensure the accelerated replication of the best genotypes.

The problem of incompatibility of the systems for recording the breeding qualities of animals in the Russian Federation and abroad, the low accuracy of conversion of indicators for assessing the breeding value of bulls in relation to the conditions of the domestic population of dairy cattle, and differences in the technology for keeping, feeding and the method of milk production (industrial and farm levels) still persists.

According to experts, the most difficult task is currently the development and implementation of up-to-date methods for assessing the genotype of bulls and cows based on domestic breeding resources, such as the Best Linear Unbiased Prediction (BLUP), economic breeding index, and the use of marker-assisted breeding and genomic forecasting. It is possible, only through the use of variations of above mentioned methods and in comparison with the traditional class assessment (appraisal), to speed up the breeding process 1.5 to 2.0 times (the frequency of changing animal generations), increase the accuracy of the breeding value forecast by $15 \%$ to $30 \%$, and thus to form the basis for the creation of highly productive herds of dairy cattle and breeding groups of animals in order to replicate the best (outstanding) genotypes of ancestors [12].

Current methods of genomic selection make it possible to identify genes responsible for the transmission of increased productivity, resistance to diseases and their fixation in the population $[13,14,15]$.

Therefore, the basis for increasing the efficiency of dairy farming and, as a consequence, increasing milk production is the genetic improvement of the breeding base, which should be based on the latest scientific achievements, the development and implementation of up-to-date systems for improving economic and biological qualities.

Scientific and educational organizations subordinated to the Ministry of Education and Science (L.K. Ernst Federal Research Center for Animal Husbandry, Vavilov Institute of General Genetics, FSC Institute of cytology and genetics SB RAS, Belgorod State National Research University and others) and to the Ministry of Agriculture of Russia (All-Russian Research Institute of Animal Breeding, Stavropol State Agrarian University and others), pedigree livestock breeding organizations, breed associations, artificial insemination organizations (Head Center for Reproduction Farm Animals that includes 26 breeding enterprises), regional information and selection centers, embryo transplantation organizations, leading breeding plants engaged in the selection and breeding of dairy cattle, gene pool farms, laboratories for selection control of milk quality and molecular-genetic examination, etc.

The All-Russian Research Institute of Animal Breeding conducts research on the development of the livestock breeding base in Russia and increasing the competitiveness of domestic breeding products. The institute has a cattle breeding laboratory, based on which a selection center for breeding red-motley dairy cattle operates, coordinates breeding work 
with the breed and improves the breed using domestic and also the world gene pool [16]. A Yearbook is published on breeding work in dairy cattle breeding in the farms of the Russian Federation, which analyzes information on the results of selection and breeding work of the country's breeding farms.

All-Russian Scientific Research Institute of Genetics and Breeding of Agricultural Animals, a branch of the L.K. Ernst Federal Research Center for Animal Husbandry, develops the foundations of breed creation, animal breeding programs, feeding systems, etc. [17].

The dairy laboratory of the Department of Dairy and Beef Cattle Breeding of the Russian State Agrarian University - Moscow Timiryazev Agricultural Academy, the laboratory for selection control of milk quality, a separate structural subdivision of the Krasnodar Scientific Center for Animal Science and Veterinary Medicine, the Siberian Scientific Research and Design Technological Institute of Animal Husbandry of the Siberian Federal Scientific Center of Agrobiotechnology of the Russian Academy of Sciences, etc., perform staff training and research activities [17].

The material and technical facilities of genetic improvement of the breeding base will be provided by the equipment existing in the scientific and educational organizations of the country, as well as in a number of commercial organizations in order to perform highperformance phenotyping of cows according to the indicators of the composition and properties of milk (e.g. using equipment of the Federal Scientific Agroengineering Center VIM, Moskovskoe OJSC for breeding, Nevskoye OJSC for breeding work, Agroplem CJSC, etc.) and to perform DNA chip genotyping (e.g. using equipment of the Miratorg Group, Geno-Analytica CJSC, Skolkovo Institute of Science and Technology, L.K. Ernst Federal Research Center for Animal Husbandry, Belgorod State National Research University, etc.)

The main reason hindering the development of the dairy farming industry is the absence of any domestic breeding value genomic assessment system that underlies on a reference population. Based on the study of the genome, a mathematical system for calculating the genomic index should be developed. The minimum sample for it should be at least 1,000 bulls and 10,000 to 15,000 bulls would be optimal sample to obtain a highly accurate prediction at the level of $70 \%$ to $80 \%$. Requirements for inclusion each animal in the reference population are the availability of biological material for research and reliable data on productivity of at least 10 to 20 offspring. The Head Center for the Reproduction of Farm Animals, the largest breeding enterprise in Russia that provides $70 \%$ of the Russian market with breeding material for reproduction and artificial insemination of cattle contains only a little more than 1,010 dairy servicing bulls. The research also requires highly qualified specialists and expensive equipment.

To solve this problem, pilot projects on genotyping of breeding animals and the formation of a database on cattle breeds in regional information and breeding centers (RIBC) have been launched. In order to form the primary Russian reference population, biological material has been collected from more than 1,150 breeding bulls from 21 breeding enterprises. The samples have been analyzed on DNA microarrays (Illumina BovineSNP50 BeadChip) that allow analyzing more than 56,000 genome polymorphisms at a time. Then associative studies of three main breeding traits of the dairy productivity, such as milk yield, mass fraction of fat and protein content in milk, have been performed.

As a result, the most reliable database of 44 regions of the Russian Federation has been created based on the database of the All-Russian Research Institute of Animal Breeding on the productivity of the daughters of all breeding bulls living in the breeding farms of Russia. Together with Geno-Analytica CJSC, productivity indicators were systematized and recalculated using the Best Liner Unbiased Prediction (BLUP) method taking into account influencing factors, and the identification of each breeding bull has been refined. 
Bioinformatics specialists have identified the relationships between thousands of polymorphisms in the Bostaurus genome and the degree of manifestation of the trait. For the first time in the world, data has been obtained for the Black-and-White Holsteinized breed, which prevails in dairy farming in Russia.

Work is underway to create a mathematical model for calculating genomic indices on a sample of animals with known performance indicators and subsequent verification on a control sample. Comparison between real values and theoretically calculated ones based on the analysis of their genome indicates a certain accuracy of the developed system for calculating the genomic index of the breeding value despite the limited sample. Work on genotyping of breeding animals continues in order to increase the reference population and subsequent calibration of the system $[19,20]$.

Considering the above, it is advisable to focus scientific attention on solving the following problems:

- Improvement of methods for assessing the genetic potential of dairy cattle including using genomic and bioinformation technologies,

- Development of effective breeding programs for dairy breeds,

- Assessment of the bioresource potential of the domestic gene pool of cattle breeds and the development of effective breeding programs,

- Improvement of reproductive technologies for the accelerated creation and replication of the best genotypes including technologies for embryonic selection.

The tasks listed and such problems of the development of the dairy cattle breeding industry as an insufficient level of pedigree recording of cows (phenotyping) according to the characteristics of productivity and genomic selection, as well as the existing technological and methodological lag in the development of reproductive technologies can be solved using the existing scientific potential. Acceleration will be facilitated by its implementation in the form of comprehensive scientific and technical projects of the subprogram titled "Improving the genetic potential of dairy cattle" of the Federal Scientific and Technical Program for the Development of Agriculture for 2017-2025.

\section{Conclusions}

Milk and dairy products play an important role in human nutrition. However, the current consumption of dairy products in Russia is significantly lower than the consumption standards recommended by the Ministry of Health. The government has set tasks to increase the output of agricultural products and improve their quality, as well as to ensure the level of self-sufficiency of Russia in dairy products in accordance with the threshold value specified in the Doctrine of Food Security.

The basis for increasing milk production is genetic improvement of the breeding resources, which should be based on the latest scientific advances. The scientific potential of the industry includes scientific and educational organizations subordinate to the Ministry of Education and Science and to the Ministry of Agriculture of Russia, breeding organizations, gene pool farms, laboratories, etc.

The genomic approach makes it possible to predict the breeding value of animals before offspring with a certain degree of reliability and leave the best ones for the next generation of breeding stock. Current methods make it possible to identify genes responsible for the transmission of increased productivity, resistance to diseases and their fixation in the population.

The analysis made it possible to formulate reasons hindering the development of the dairy cattle breeding industry in Russia, one of which is the absence of any domestic system for the genomic assessment of the breeding value based on the domestic reference population. To solve the problem, information on the productivity of more than 1 million 
animals has been analyzed. A system has been developed to optimize data on the origin of animals to build an accurate relationship matrix. The relationship between genome polymorphisms and the degree of manifestation of a trait has been determined. A mathematical model is being created to calculate genomic indices.

It is proposed to focus scientific research on improving methods for assessing the genetic potential of dairy cattle, developing effective breeding programs for dairy breeds, assessing the biological resource potential of the domestic gene pool and developing programs for their breeding and improving reproductive technologies for creating and replicating the best genotypes. These tasks, as well as the problems associated with the insufficient level of phenotyping and genomic selection can be solved by the existing scientific potential as the performed analysis has showed. Acceleration will be facilitated by their implementation in the form of comprehensive scientific and technical projects of the subprogram titled "Improving the genetic potential of dairy cattle" of the Federal Scientific and Technical Development Program.

\section{References}

1. Soyuzmoloko: in 2020, the average per capita milk consumption in Russia was $240 \mathrm{~kg}$, retrieved from: https://www.oilworld.ru/news/milk/317357 (accessed on 01.02.2021)

2. Text broadcast: XII Congress of the National Union of Milk Producers retrieved from:https://milknews.ru/index/novosti-moloko_62164.html (accessed on 01.02.2021)

3. T.E. Marinchenko, IOP Conf. Series: Materials Science and Engineering, 873, 012004 (2020)

4. A. Korolkova, T. Marinchenko, A. Goryacheva, IOP Conference Series: Earth and Environmental Science, 604(1), 012005 (2020)

5. T.E. Marinchenko, IOP Conf. Ser.:Earth Environ. Sci. 624012080 (2021)

6. Agribusiness Export Products federal project data sheet, retrieved from: http://mcx.ru/ministry/departments/departament-informatsionnoy-politiki-ispetsialnykh-proektov/industry-information/info-pasport-federalnogo-proekta-eksportproduktsii-apk/ (accessed on: 28.02.2020)

7. D.A. Magee et al., BioMed Central Genetics (2010), retrieved from: https://bmcgenet.biomedcentral.com/articles/10.1186/1471-2156-11-93 (accessed on: 01.12.2018)

8. M. Singh, A. Arya, A.P. Singh, A.K. Chakravarty, M.A. Mir, Indian Journal of Animal Research, 54(3), 275-281 (2020)

9. Qianqian Zhang, M.P.L. Calus, M. Bosse, G. Sahana, M.S. Lund, B. Guldbrandtsen, Genetics, 209, 4 (2018)

10. 2019 yearbook on breeding work in dairy cattle breeding on the farms of the Russian Federation (Moscow: VNIIplem) (2020)

11. E.A. Matveeva, E.E. Tyapugin, L.P. Bogolyubova, S.V. Nikitina, N.V. Semenova, S.E. Tyapugin, A.A. Kochetkov, Dairy and meat cattle breeding, 8, 3-6 (2020)

12. P.S. Bugrov, N.V. Ivanov, D. Abylkassymov, N.P. Sudarev, Dairy and meat cattle breeding, 8, 27-30 (2016)

13. M. Rahman, R. Islam, M.M. Rahman, M. Haque, T. Das, Asian Journal of Animal and Veterinary Advances, 2, 9-14 (2007)

14. E. Missanjo, V. Imbayarwo-Chikosi, T. Halimani, ISRN Veterinary Science (2013) 
15. I. Strandén, J. Kantanen, I.-R.M. Russo, P. Orozco-terWengel, M.W. Bruford, Heredity, 123(3), 307-317 (2019)

16. N.G. Bukarov, T.A. Knyazeva, A.A. Novikov, A.I. Khrunova, N.S. Marzanov, Dairy and meat cattle breeding, 5, 8-12 (2016)

17. S.D. Batanov, O.S. Starostina, I.A. Baranova, IOP Conference Series: Earth and Environmental Science, 548, 32023 (2020)

18. A.I. Tikhomirov, T.E. Marinchenko, Machinery and equipment for rural area, 11(281), 44-50 (2020)

19. Russia is developing the first own system of genomic assessment of the breeding value of livestock, retrieved from: https://www.kommersant.ru/doc/2624075 (accessed on: 28.01.2021)

20. D.Yu. Suslov, A.V. Voevodin, S.A. Holev, S.E. Tyapugin, Dairy and meat cattle breeding, 1, 9-11 (2018) 